\title{
Glucose prediction by analysis of exhaled metabolites - a systematic review
}

\author{
Jan Hendrik Leopold ${ }^{1,2^{*}}$, Roosmarijn TM van Hooijdonk' ${ }^{1}$ Peter J Sterk ${ }^{3}$, Ameen Abu-Hanna², Marcus J Schultz ${ }^{1}$ \\ and Lieuwe DJ Bos ${ }^{1,3}$
}

\begin{abstract}
Background: In critically ill patients, glucose control with insulin mandates time- and blood-consuming glucose monitoring. Blood glucose level fluctuations are accompanied by metabolomic changes that alter the composition of volatile organic compounds (VOC), which are detectable in exhaled breath. This review systematically summarizes the available data on the ability of changes in VOC composition to predict blood glucose levels and changes in blood glucose levels.
\end{abstract}

Methods: A systematic search was performed in PubMed. Studies were included when an association between blood glucose levels and VOCs in exhaled air was investigated, using a technique that allows for separation, quantification and identification of individual VOCs. Only studies on humans were included.

Results: Nine studies were included out of 1041 identified in the search. Authors of seven studies observed a significant correlation between blood glucose levels and selected VOCs in exhaled air. Authors of two studies did not observe a strong correlation. Blood glucose levels were associated with the following VOCs: ketone bodies (e.g., acetone), VOCs produced by gut flora (e.g., ethanol, methanol, and propane), exogenous compounds (e.g., ethyl benzene, o-xylene, and $\mathrm{m} / \mathrm{p}$-xylene) and markers of oxidative stress (e.g., methyl nitrate, 2-pentyl nitrate, and CO).

Conclusion: There is a relation between blood glucose levels and VOC composition in exhaled air. These results warrant clinical validation of exhaled breath analysis to monitor blood glucose levels.

Keywords: Glucose, Monitoring, Volatile organic compound, Breath

\section{Background}

Many, if not all, critically ill patients are treated with insulin at some point during their stay in the intensive care unit (ICU) [1]. Intensive monitoring of the blood glucose level is a prerequisite for both efficient and safe insulin titration in these patients [2]. Current practice in the ICU holds that glucose levels are monitored manually through intermittent measurements of the blood glucose level in central laboratories or using laboratory-based blood gas analyzers and/or glucose strips at the bedside [3]. Intermittent manual glucose monitoring however, is expensive and time and blood consuming [4]. Moreover, intermittent glucose monitoring lacks the ability to detect

\footnotetext{
* Correspondence: j.h.leopold@amc.uva.nl

'Department of Intensive Care, Academic Medical Center, Meibergdreef 9,

1105 AZ Amsterdam, The Netherlands

${ }^{2}$ Department of Medical Informatics, Academic Medical Center, Meibergdreef 9, 1105 AZ Amsterdam, The Netherlands

Full list of author information is available at the end of the article
}

temporal trends, potentially causing dangerous insulin titration errors in critically ill patients [5].

Glucose is a central molecule in metabolism [6,7]. Indeed, metabolic pathways are activated to maintain normoglycemia when the concentration of glucose changes $[6,8]$. Changes in the activity of these pathways could result in changes in production of volatile metabolites. These socalled volatile organic compounds (VOCs) can be detected in exhaled breath [9].

We hypothesize that there is an association between VOCs in exhaled breath and blood glucose levels. Previous excellent reviews focused on the correlation between glucose and exhaled breath condensate (thus soluble markers) [10] in diabetes [11,12], but none compared all available literature or discussed the implications for the ICU population. The specific aim of this systematic review is to provide an overview of the available data on the association 
breath VOCs and blood glucose levels and to discuss techniques for $\mathrm{VOC}$ detection.

\section{Methods}

This systematic review was done according to standard methodology [13,14]. Medline was searched through Pubmed using the following search terms: ("Blood Glucose"[Mesh] OR "Glucose"[MeSH Terms] OR glucose[tiab]) AND ("Exhalat"" [MeSH Terms] OR "Volatile Organic Compounds" [Mesh] OR exhal" [tiab] OR Volatile Organic Compound* [tiab] OR Volatile Compound* [tiab] OR electronic nose [tiab] OR breath [tiab]. The search was conducted on the 3rd of January 2014. No limits were used for year of publication and language. Only human studies were included, with no restriction on subject health, age, gender or study setting.

Two independent researchers (JHL, LDB) selected articles for full-text assessment when the title and abstract suggested investigating the use of exhaled breath to measure or estimate blood glucose levels. Articles were only included if an association between blood glucose levels and VOCs in exhaled air was investigated. Also, VOC compositions of exhaled air had to be measured by an analytical technique that allows for separation, quantification and identification of individual VOCs, including gas chromatography and mass spectrometry (GC-MS), ion mobility mass spectroscopy (IMS), ion_molecule reaction mass spectrometry (IMR-MS), proton transfer reaction (time of flight) mass spectrometry (PTR(-TOF)-MS) and/ or selected ion flow tube mass spectrometry (SIFT-MS).

Data from included studies were extracted and methodological quality was assessed independently by two researchers (JHL, LDB) using the QUADAS-2 tool for quality assessment [15]. The tool was adapted to be more relevant to the included literature. Disagreement between the two reviewers on inclusion of studies was resolved by consensus. The adjusted version of QUADAS-2 is presented in Additional file 1. Extracted data included: 1) characteristics of the study (design, year of publication and country of study conduction); 2) characteristics of the study population (including age, sex distribution and health status); 3) characteristics of the index test (including technique and included VOCs); 4) characteristics of the reference standard (blood glucose); 5) characteristics of the outcome (including main results and correlation coefficient between exhaled breath and glucose); 6) statistical validation technique used.

\section{Results}

\section{Search results}

The literature search in Pubmed yielded 1041 titles (Figure 1). After reading titles and abstracts, 1012 articles were excluded because the topic was outside of the scope of this review and 29 articles were retained for

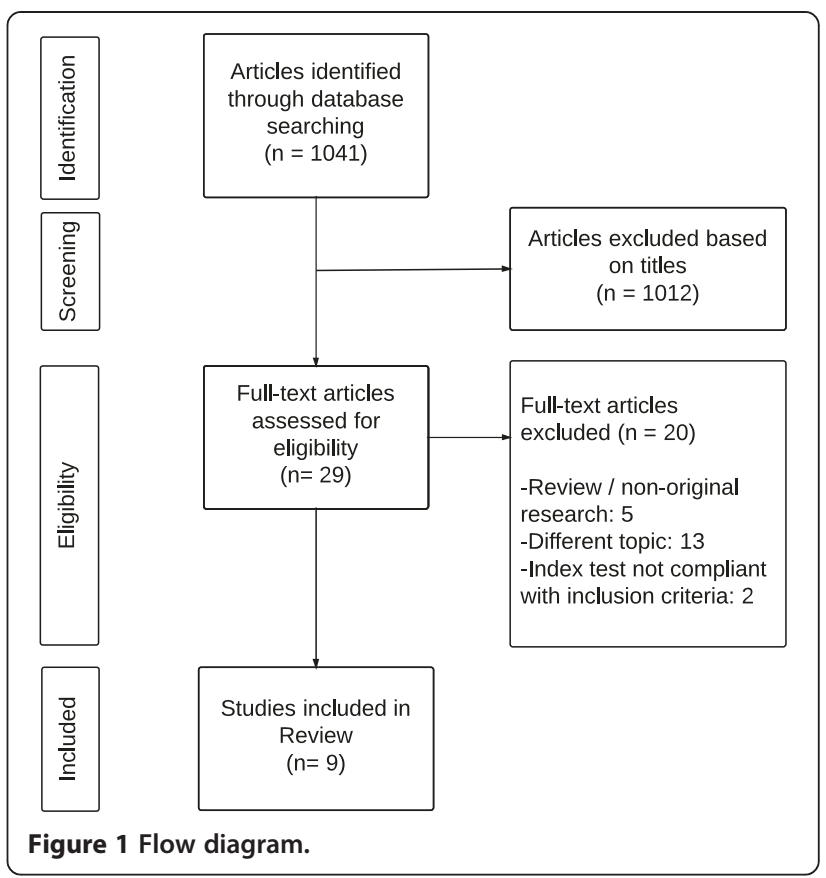

full-text assessment. After the exclusion of 20 papers (5 reviews/non-original studies, 13 on unrelated topics, 2 index test not compliant with inclusion criteria), 9 articles were included in the analysis. Characteristics of selected articles are presented in Table 1. Five studies included healthy non-diabetic subjects, two studies included Type 1 Diabetes Mellitus (T1DM) subjects, one study included Type 2 Diabetes Mellitus (T2DM) subjects and one study included both healthy and T1DM subjects.

Results of the quality assessment using the QUADAS2-tool are presented in Table 2. The risk of bias was considered high for all studies; none of the studies used a random sample of patients, all using a pre-specified target group such as T1DM or T2DM patients. The use of blood gas measurements or central lab measurements was considered to be the correct reference standard [16]. The adequate reference standard was used in four studies. Four studies used finger prick measurement, which increases the possibility of incorrect insulin titration in clinical practice [16]. Comparing these measurements to exhaled breath could lead to biased results. However, none of these studies were excluded from our review.

\section{Point correlation}

Authors of seven out of nine studies found a strong correlation between one or more metabolites in exhaled breath and blood glucose levels, with a mean linear regression coefficient of 0.82 [range: 0.08-0.98] (Table 1). However, none of the included studies validated their results internally (e.g. cross-validation) or externally (e.g. in an separate validation cohort). A total of ten metabolites have been reported to correlate with blood glucose 
Table 1 Characteristics of included studies

\begin{tabular}{|c|c|c|c|c|c|c|c|c|}
\hline First Author & Setting & Patients & Age & $\begin{array}{l}\text { Sex } \\
\text { distribution }\end{array}$ & Index test & $\begin{array}{l}\text { Reference } \\
\text { standard }\end{array}$ & Main Results & Mean correlation coefficient \\
\hline Righettoni [17] & $\begin{array}{l}\text { Healthy subjects } \\
\text { sampled after } \\
\text { overnight fast and } \\
\text { after lunch. }\end{array}$ & 8 & $\begin{array}{l}22-55 \\
\text { years }\end{array}$ & $\begin{array}{l}7 \text { male, } 1 \\
\text { female }\end{array}$ & $\begin{array}{l}\text { PTR-TOF-MS: Acetone, } \\
\text { ethanol, methanol, } \\
\text { isoprene Nano sensing } \\
\text { films: Breath acetone }\end{array}$ & $\begin{array}{l}\text { Finger prick } \\
\text { measurement } \\
\text { with Bayer } \\
\text { Contour Blood } \\
\text { Glucose Meter }\end{array}$ & $\begin{array}{l}\text { After overnight fast a high } \\
\text { correlation between sensors and } \\
\text { glucose, and acetone, ethanol, } \\
\text { methanol and glucose was found. } \\
\text { These high correlations were not } \\
\text { found after lunch. }\end{array}$ & $\begin{array}{l}\text { Morning: PTR-TOF-MS: Acetone:0.98 } \\
\text { Ethanol:0.9 Methanol: . } 93 \text { Iso } \\
\text { prene:0.00 Nano sensing films: } 0.96 \\
\text { Afternoon: PTR-TOF-MS: Acetone:- } \\
\text { 0.08 Ethanol:0.11 Methanol:-0.16 } \\
\text { Isoprene:-0.40 Nano sensing } \\
\text { films: }-0.02\end{array}$ \\
\hline Storer [18] & $\begin{array}{l}\text { T2DM subjects not } \\
\text { asked to fast but to } \\
\text { refrain from eating. } \\
\text { Cross-sectional study }\end{array}$ & $38, \mathrm{~T} 2 \mathrm{DM}$ & $\begin{array}{l}32-76 \\
\text { years, } \\
\text { median } \\
\text { age } 62\end{array}$ & $\begin{array}{l}13 \text { male, } \\
25 \text { female }\end{array}$ & SIFT-MS: Acetone & $\begin{array}{l}\text { Finger prick } \\
\text { measurement } \\
\text { with Abbot } \\
\text { Optium Xceed }\end{array}$ & $\begin{array}{l}\text { No strong correlation found } \\
\text { between blood glucose and breath } \\
\text { acetone. Breath acetone was found } \\
\text { to be significantly higher in men. }\end{array}$ & $r=0.003$ \\
\hline Minh [22] & $\begin{array}{l}\text { Clamp study. } \\
\text { Overnight fast. } \\
\text { T1DM subjects were } \\
\text { asked not to take } \\
\text { long acting insulin. }\end{array}$ & $\begin{array}{l}25(17 \\
\text { healthy, } \\
8 \text { T1DM) }\end{array}$ & $\begin{array}{l}\text { Healthy: } \\
28 \pm \\
1 \text { years } \\
\text { T1DM: } \\
25,8 \pm \\
1,7 \text { years }\end{array}$ & $\begin{array}{l}11 \text { male, } \\
14 \text { female }\end{array}$ & $\begin{array}{l}\text { GCMS: Group A (Ethanol, } \\
\text { acetone, methyl nitrate, } \\
\text { ethyl-benzene) Group B (2- } \\
\text { pentyl nitrate, propane, } \\
\text { methanol, ethanol) Room } \\
\text { samples collected. }\end{array}$ & $\begin{array}{l}\text { IV catheters in } \\
\text { antecubital } \\
\text { veins; } \\
\text { Beckman } \\
\text { Glucose } \\
\text { analyzer II }\end{array}$ & $\begin{array}{l}\text { Group A: healthy, mean r of } 0.836 \text {, } \\
\text { T1DM, mean r of } 0.950 \text {. B: healthy, } \\
\text { mean r of } 0.829, \text { T1DM, mean r of } \\
0.920 \text {. }\end{array}$ & Healthy: $r=0.8325$ T1DM: $r=0.935$ \\
\hline Turner [21] & $\begin{array}{l}\text { Clamp study. } \\
\text { Overnight fast. } \\
\text { T1DM subjects }\end{array}$ & $8, \mathrm{~T} 1 \mathrm{DM}$ & $\begin{array}{l}28 \pm \\
3 \text { years }\end{array}$ & & SIFT-MS: Acetone & $\begin{array}{l}\text { IV distal } \\
\text { catheter in } \\
\text { hand. Hand } \\
\text { warmed to } \\
\text { arterialize the } \\
\text { sample. YSI. }\end{array}$ & $\begin{array}{l}\text { No strong correlation at baseline. } \\
\text { Linear correlation between acetone } \\
\text { and blood glucose values. Breath } \\
\text { acetone decreased when blood } \\
\text { glucose decreased. In healthy } \\
\text { volunteers the opposite was seen: } \\
\text { Low blood glucose values yield high } \\
\text { acetone values. }\end{array}$ & $r=0.816(0.598-0.940)$ \\
\hline Lee [20] & $\begin{array}{l}\text { Clamp study. } \\
\text { Healthy subjects } \\
\text { admitted to lab after } \\
\text { overnight fast. }\end{array}$ & 10 & $\begin{array}{l}26 \pm \\
4 \text { years }\end{array}$ & $\begin{array}{l}5 \text { male, } \\
5 \text { female }\end{array}$ & $\begin{array}{l}\text { GCMS: Ethanol, Acetone, } \\
\text { Methyl nitrate, } \\
\text { ethylbenzene, o-oxylene, } \\
\text { m/p-xylene. Room samples } \\
\text { collected. }\end{array}$ & $\begin{array}{l}\text { IV catheters in } \\
\text { antecubital } \\
\text { veins; } \\
\text { Beckman } \\
\text { Glucose } \\
\text { analyzer II }\end{array}$ & $\begin{array}{l}\text { Best } 4 \text { gas model: Ethanol, acetone, } \\
\text { methyl nitrate, ethyl benzene (mean } \\
\text { r of } 0.913(0.698-0.977)) 9 \text { samples } \\
\text { per patient }\end{array}$ & $r=0.913(0.698-0.977)$ \\
\hline Fritsch [19] & $\begin{array}{l}\text { OGTT. Healthy } \\
\text { volunteers admitted } \\
\text { after } 10 \text { hours fast. }\end{array}$ & 6 & $\begin{array}{l}24-32 \\
\text { years }\end{array}$ & $\begin{array}{l}5 \text { male, } \\
1 \text { female }\end{array}$ & $\begin{array}{l}\text { Electrochemical analyzer, } \\
\text { laser spectrometer, and } \\
\text { breath hydrogen: Carbon } \\
\text { monoxide measured with } \\
\text { Micro smokerlyzer. }\end{array}$ & $\begin{array}{l}\text { Finger prick } \\
\text { measurement, } \\
\text { Accu check } \\
\text { Aviva. }\end{array}$ & $\begin{array}{l}\text { No strong correlation between } \\
\text { glucose and carbon monoxide }\end{array}$ & None \\
\hline Novak [39] & $\begin{array}{l}\text { Clamp study. T1DM } \\
\text { subjects admitted } \\
\text { after eating light } \\
\text { breakfast. Patients } \\
\text { on insulin followed } \\
\text { normal regimen. }\end{array}$ & 10, T1DM & $\begin{array}{l}13,8 \pm \\
0,5 \text { years }\end{array}$ & $\begin{array}{l}7 \text { male, } \\
3 \text { female }\end{array}$ & $\begin{array}{l}\text { GCMS: Methyl nitrate } \\
\text { Room samples collected. }\end{array}$ & $\begin{array}{l}\text { IV lines in } \\
\text { arms, Blood } \\
\text { samples every } \\
30 \text { min. } \\
\text { Beckman }\end{array}$ & $\begin{array}{l}\text { Methyl nitrate had strongest } \\
\text { correlation with blood glucose } \\
\text { levels. Correlation increased with 30- } \\
\text { minute lag time. Ethanol and Acet- } \\
\text { one DID NOT correlate with glucose }\end{array}$ & One subject mentioned, $r=0.99$ \\
\hline
\end{tabular}


Table 1 Characteristics of included studies (Continued)

\begin{tabular}{|c|c|c|c|c|c|c|c|c|}
\hline & & & & & & $\begin{array}{l}\text { glucose } \\
\text { analyzer II }\end{array}$ & & \\
\hline Galassetti [32] & $\begin{array}{l}\text { OGTT. Healthy } \\
\text { subjects admitted to } \\
\text { research center in } \\
\text { morning after } \\
\text { overnight fast. }\end{array}$ & 10 & $\begin{array}{l}27,4 \pm \\
3,1\end{array}$ & $\begin{array}{l}5 \text { male, } 5 \\
\text { female }\end{array}$ & $\begin{array}{l}\text { GCMS: Ethanol and } \\
\text { acetone. Room samples } \\
\text { collected. }\end{array}$ & $\begin{array}{l}\text { IV catheter. } \\
\text { Determined } \\
\text { with a } \\
\text { quantitative } \\
\text { enzymatic } \\
\text { measurement. }\end{array}$ & $\begin{array}{l}\text { Multiple linear regression analysis } \\
\text { with ethanol and acetone gave an } \\
\text { average } r \text { of } 0.70 \text {. }\end{array}$ & $r=0.700$ \\
\hline Paredi [27] & $\begin{array}{l}\text { OGTT in } 5 \text { patients, } \\
\text { CO and glucose } \\
\text { measured. Only CO } \\
\text { measured in larger } \\
\text { cohort }\end{array}$ & 5 & $\begin{array}{l}33 \pm \\
4 \text { years }\end{array}$ & $\begin{array}{l}3 \text { male, } 2 \\
\text { female }\end{array}$ & $\begin{array}{l}\text { Micro smokerlyzer: Carbon } \\
\text { monoxide }\end{array}$ & $\begin{array}{l}\text { Finger prick } \\
\text { measurement, } \\
\text { Reflolux S. }\end{array}$ & $\begin{array}{l}\text { The maximal glucose increase was } \\
\text { associated with a significant increase } \\
\text { in exhaled CO concentration. Both } \\
\text { parameters returned to the baseline } \\
\text { at } 40 \text { min after glucose } \\
\text { administration. }\end{array}$ & Unknown \\
\hline
\end{tabular}


Table 2 Results of QUADAS-2 tool

\begin{tabular}{|c|c|c|c|c|c|c|c|c|}
\hline \multirow[t]{2}{*}{ Study } & \multicolumn{4}{|l|}{ Risk of Bias } & \multicolumn{3}{|c|}{ Applicability Concerns } & \multirow[b]{2}{*}{ Comments } \\
\hline & Patient selection & $\begin{array}{l}\text { Index } \\
\text { test }\end{array}$ & $\begin{array}{l}\text { Reference } \\
\text { standard }\end{array}$ & $\begin{array}{l}\text { Flow and } \\
\text { timing }\end{array}$ & $\begin{array}{l}\text { Patient } \\
\text { selection }\end{array}$ & $\begin{array}{l}\text { Index } \\
\text { test }\end{array}$ & $\begin{array}{l}\text { Reference } \\
\text { standard }\end{array}$ & \\
\hline $\begin{array}{l}\text { Righettoni } \\
\text { (2013) [17] }\end{array}$ & $?$ & $?$ & $x$ & $\checkmark$ & $\checkmark$ & $\checkmark$ & $\checkmark$ & $\begin{array}{l}\text { Single measurements in morning and in } \\
\text { afternoon make prediction of trend impossible. } \\
\text { Possible verification bias because of incorrect } \\
\text { reference standard. }\end{array}$ \\
\hline $\begin{array}{l}\text { Storer } \\
(2011) \text { [18] }\end{array}$ & $?$ & $x$ & $x$ & $\checkmark$ & $\times$ & $\times$ & $\checkmark$ & $\begin{array}{l}\text { Single measurement makes prediction of trend } \\
\text { impossible. Test review bias because reference } \\
\text { standard is used for index test. Possible } \\
\text { verification bias because of incorrect reference } \\
\text { standard }\end{array}$ \\
\hline $\begin{array}{l}\text { Minh } \\
\text { (2011) [22] }\end{array}$ & $?$ & $\checkmark$ & $\checkmark$ & $\checkmark$ & $\checkmark$ & $\checkmark$ & $\checkmark$ & $\begin{array}{l}\text { Clamp study design possibly lowers clinical } \\
\text { relevance because of lack of generalizability. } \\
\text { Test review bias because reference standard is } \\
\text { used for index test. }\end{array}$ \\
\hline $\begin{array}{l}\text { Turner } \\
\text { (2009) [21] }\end{array}$ & $?$ & $x$ & $\checkmark$ & $\checkmark$ & $x$ & $x$ & $\checkmark$ & $\begin{array}{l}\text { Small sample size. Clamp study design possibly } \\
\text { lowers clinical relevance because of lack of } \\
\text { generalizability. Test review bias because } \\
\text { reference standard is used for index test. }\end{array}$ \\
\hline $\begin{array}{l}\text { Lee } \\
\text { (2009) [20] }\end{array}$ & $?$ & $x$ & $\checkmark$ & $\checkmark$ & $\checkmark$ & $\checkmark$ & $\checkmark$ & $\begin{array}{l}\text { Small sample size. Clamp study design possibly } \\
\text { lowers clinical relevance because of lack of } \\
\text { generalizability. Test review bias because } \\
\text { reference standard is used for index test. }\end{array}$ \\
\hline $\begin{array}{l}\text { Fritsch } \\
\text { (2008) [19] }\end{array}$ & $?$ & $\checkmark$ & $x$ & $\checkmark$ & $\checkmark$ & $x$ & $\checkmark$ & $\begin{array}{l}\text { Small sample size. OGTT study design possibly } \\
\text { lowers clinical relevance because of lack of } \\
\text { generalizability. Test review bias because } \\
\text { reference standard is used for index test. } \\
\text { Possible verification bias because of incorrect } \\
\text { reference standard. }\end{array}$ \\
\hline $\begin{array}{l}\text { Novak } \\
\text { (2007) [39] }\end{array}$ & $?$ & $\times$ & $\checkmark$ & $\checkmark$ & $\times$ & $\checkmark$ & $\checkmark$ & $\begin{array}{l}\text { Clamp study design possibly lowers clinical } \\
\text { relevance because of lack of generalizability. } \\
\text { Test review bias because reference standard is } \\
\text { used for index test. Possible reporting error, } \\
\text { results of only one subject mentioned in detail. }\end{array}$ \\
\hline $\begin{array}{l}\text { Galassetti } \\
\text { (2005) [32] }\end{array}$ & $?$ & $x$ & $?$ & $\checkmark$ & $\checkmark$ & $\checkmark$ & $\checkmark$ & $\begin{array}{l}\text { Small sample size. OGTT study design possibly } \\
\text { lowers clinical relevance because of lack of } \\
\text { generalizability. Test review bias because } \\
\text { reference standard is used for index test. } \\
\text { Possible verification bias because of incorrect } \\
\text { reference standard }\end{array}$ \\
\hline $\begin{array}{l}\text { Paredi } \\
\text { (1999) [27] }\end{array}$ & $?$ & $\checkmark$ & $x$ & $\checkmark$ & $\checkmark$ & $\times$ & $\checkmark$ & $\begin{array}{l}\text { Small sample size. OGTT study design possibly } \\
\text { lowers clinical relevance because of lack of } \\
\text { generalizability. Possible verification bias } \\
\text { because of incorrect reference standard. }\end{array}$ \\
\hline
\end{tabular}

levels, including exhaled acetone, VOCs produced by gut flora (ethanol, methanol, and propane), exogenous compounds (Ethyl benzene, o-xylene, and $\mathrm{m} / \mathrm{p}$-xylene) and VOCs that reflect oxidative status (methyl nitrate, 2pentyl nitrate, and carbon monoxide (CO)) (Table 3). Authors of two studies did not observe a strong correlation. The first one of those did not find a significant correlation between a single measurement of breath acetone and blood glucose in T2DM subjects. Authors of the second study were unable to demonstrate a strong correlation between glucose levels and exhaled $\mathrm{CO}$ in healthy subjects. Researchers in one of the studies that did show a strong correlation between breath metabolites and glucose levels, only observed this after overnight fast, showing a weak correlation after consuming a meal [17].

\section{Temporal association}

Researchers in seven out of nine studies performed multiple measurements with an interval ranging from 2.5 to 40 minutes. Two studies had a cross-sectional design and only performed a single measurement, or two unpaired measurements. None of the authors of the included studies reported on the possibility of predicting glucose trend. 
Table 3 VOCs found to correlate with glucose levels

\begin{tabular}{|c|c|c|}
\hline VOC & Mechanism(s) & Pathway(s) \\
\hline $\begin{array}{l}\text { 2-pentyl } \\
\text { nitrate [22] }\end{array}$ & $\begin{array}{l}\text { Generated through pathways involving organic peroxy radical (RO2-) with } \mathrm{NO} \text { or } \mathrm{NO} 2 \text {. Could be } \\
\text { modulated by acute changes in systematic oxidative status [22]. }\end{array}$ & \\
\hline $\begin{array}{l}\text { Acetone } \\
{[20-22,32]}\end{array}$ & $\begin{array}{l}\text { Derived from acetoacetate and is produced by synthesis and degradation of ketone bodies and is } \\
\text { therefore related to blood glucose levels [32]. }\end{array}$ & $\begin{array}{l}\text { Glycolysis/Pyruvate } \\
\text { metabolism }\end{array}$ \\
\hline $\begin{array}{l}\text { Cabon } \\
\text { monoxide [27] }\end{array}$ & $\begin{array}{l}\text { Possibly due to activation of } \mathrm{HO} \text { by glucose, and the positive modulation of } \mathrm{CO} \text { non insulin } \\
\text { secretion [27]. }\end{array}$ & \\
\hline $\begin{array}{l}\text { Ethanol } \\
{[20,22,32]}\end{array}$ & $\begin{array}{l}\text { Not produced by mammalian cells. Likely due to alcoholic fermentation of glucose } \\
\text { by gut bacteria and yeast [32]. }\end{array}$ & Glycolysis/Gluconeogenesis \\
\hline $\begin{array}{l}\text { Ethyl benzene } \\
{[20,22]}\end{array}$ & $\begin{array}{l}\text { Inhaled and partly metabolized by liver, then exhaled at lower concentration. Rapid-onset } \\
\text { hyperglycemia likely suppressed hepatic metabolism causing peaks in exhaled air [20]. }\end{array}$ & \\
\hline $\begin{array}{l}\text { M/P-xylene } \\
{[20]}\end{array}$ & $\begin{array}{l}\text { Inhaled and partly metabolized by liver, then exhaled at lower concentration. Rapid-onset } \\
\text { hyperglycemia likely suppressed hepatic metabolism causing peaks in exhaled air [20]. }\end{array}$ & \\
\hline Methanol [22] & Reflects gut flora activity and therefore responsive to glycemic fluctuations [22]. & \\
\hline $\begin{array}{l}\text { Methyl nitrate } \\
{[22,39]}\end{array}$ & $\begin{array}{l}\text { A small fraction of superoxide ion }(\mathrm{O} 2--) \text {, a byproduct of oxidative reactions, reacts with nitric oxide } \\
\text { which in turn can react with methanol to eventually form an isomer of Methyl nitrate [39]. }\end{array}$ & \\
\hline O-xylene [20] & $\begin{array}{l}\text { Inhaled and partly metabolized by liver, then exhaled at lower concentration. Rapid-onset } \\
\text { hyperglycemia likely suppressed hepatic metabolism causing peaks in exhaled air [20]. }\end{array}$ & \\
\hline Propane [22] & Reflects gut flora activity and therefore responsive to glycemic fluctuations [22]. & $\begin{array}{l}\mathrm{N}-4 \text { fatty acid Peroxidation } \\
\text { Protein oxidation }\end{array}$ \\
\hline
\end{tabular}

\section{Discussion}

This systematic review identified nine studies that investigated the ability of exhaled breath to measure or estimate blood glucose levels. A significant correlation between VOCs in exhaled breath and blood glucose levels was found in seven studies. These results indicate that there is an association between the two, although not all studies are consistent. Researchers in one of these seven studies only found a strong correlation after overnight fasting of the subjects and were unable to replicate the results after a meal [17]. Authors of two negative studies did not find a strong correlation, possibly due to a different study design [18] and the VOC (e.g. CO) that was studied [19]. Authors of the study that included subjects with T2DM did not show a significant correlation between exhaled VOCs and blood glucose levels. This study also had a different (cross-sectional) design. The analytical technique used for VOC detection did not modify the reported correlation. None of the studies monitored breath continuously. Also the glucose trend, thus the temporal association between glucose and exhaled VOCs, was not explicitly investigated. However, the data from three longitudinal studies [20-22] suggest that trends in glucose levels could possibly be monitored using exhaled breath when measurements are taken more frequently.

\section{Index tests: exhaled breath analysis}

A significant correlation between metabolites in exhaled breath and blood glucose levels was found using GCMS, SIFT-MS, PTR-TOF-MS, a nano-sensing film-based sensor, and an electrochemical analyzer as analytical method. GC-MS is considered to be the gold standard for VOC detection and has shown to have a high sensitivity to identify single VOCs [23]. Therefore, GC-MS is suitable to accurately quantify a number of different VOCs in a cross-sectional study. However, the timeconsuming nature of the technique limits use of the device for real-time and continuous measurements, which hampers clinical application. Other analytical techniques such as SIFT-MS [22,23] and PTR-TOF-MS [23-25] can also identify single VOCs and can be used for real-time continuous measurements. Disadvantages include possible selection bias [26] and the limitation to the concentration range that can be detected [25].

The electrochemical analyzers used in selected studies are two different Smokerlyzer Micro (Bedfont, UK) devices. These devices measure the amount of $\mathrm{CO}$ in exhaled breath. However, there is a cross sensitivity to hydrogen [19]. While a correlation between exhaled CO and glucose levels was found by the researchers of one study [27], researchers of another study [19] could not reproduce these findings. Contrasting results may be due to the high cross sensitivity to hydrogen in the electrochemical analyzer used previously [27], which was less apparent using a newer device [19]. This exemplifies the importance of an adequate analytical technique that suits the aim of the study.

An important limitation of the techniques used in included studies is that none of them was used to continuously monitor exhaled breath. Continuous analysis of the exhaled breath was previously described by means of IMR-MS [28], PTR-MS [24], and electronic nose $[29,30]$. After a training phase, electronic noses learn to recognize specific disease states and can therefore be 
used for classification. The devices cannot identify and quantify single VOCs, but they do give a rapid, bedside diagnosis, which, from a clinical perspective, renders this device attractive. The electronic nose has been used to discriminate between patients with and without diabetes [31]. One could postulate that the ability to diagnose diabetes is partly due to the metabolomic alterations because of higher blood glucose levels in diabetic patients. Therefore, electronic nose analysis may complement mass-spectrometry based techniques for the monitoring of blood glucose levels in clinical practice, providing signals based on probabilistic training and validation. Alternatively to semi-selective recognition, nanosensors also rely on specific recognition of certain VOCs [30]. In one study, an acetone-selective nanomaterial-based sensor was used alongside PTR-TOF-MS and showed a strong correlation between acetone, glucose and the sensor [17]. Small size of devices using nanomaterial-based sensors as compared to spectrometry-based methods facilitates clinical application.

\section{VOCs associated with blood glucose levels}

Mechanisms related to the association between VOCs and glucose levels can be found in Table 3. Acetone appeared to be associated with blood glucose levels $[17,20-22,32]$. As a result of increased synthesis of acetone and degradation of ketone bodies, acetone is expected to be higher in diabetics [33]. On the other hand, healthy humans only have elevated levels of ketone bodies when fasting or exercising [11]. Therefore, it is more likely to find a correlation between exhaled acetone and glucose levels after fasting compared to finding a correlation after lunch [17]. Acetone possibly is a good marker for glucose levels in ICU-patients. However, the large variation in breath acetone levels between subjects [18,34-36] may result in low accuracy when using acetone cross-sectionally.

VOCs such as ethanol $[17,20,22,32]$, propane [22] and methanol $[17,22]$ are likely to reflect gut flora activity, since the metabolism of gut bacteria is responsive to glycemic fluctuations [22,32]. However, we cannot exclude that other biochemical pathways also contribute to the production of these compounds. In critically ill patients on the ICU, the quantity and composition of the gut microbiome are changing over time and therefore the amount of VOCs they produce may not be stable [37] Therefore, these markers are less likely to predict glucose levels in ICU-patients.

Ethyl benzene [20,22], o-xylene [20] and m/p-xylene [20] are gasses that are inhaled, partially metabolized by the liver and subsequently exhaled at lower concentrations [20]. Rapid-onset hyperglycemia likely suppresses hepatic metabolism, thus causing peak concentrations of these compounds in exhaled air. Recent evidence suggests that cyclic hydrocarbons such as ethyl benzene and xylene are emitted by the ventilator and tubing [38]. Given that exhaled air is readily accessible for measurements in mechanically ventilated ICU patients, use of exhaled air for the prediction of glucose levels is therefore plausible.

An isomer of methyl nitrate [22,39] is formed when methanol reacts with nitric oxide, which in turn reacts with superoxide ion $\left(\mathrm{O}_{2}^{-}\right)$, a by-product of oxidative reactions [39]. Furthermore, 2-pentyl nitrate [22] is generated through pathways involving organic peroxy radical $\left(\mathrm{RO}_{2}\right)$ and $\mathrm{NO}$ or $\mathrm{NO}_{2}$. This could be modulated by acute changes in systematic oxidative status [22]. Changes in $\mathrm{CO}[27]$ in exhaled breath are possibly related to oxidative stress. When glucose levels rise, particularly in diabetic patients, this can lead to oxidative stress. As a protective response, heme oxygenase is activated, leading to the positive modulation of $\mathrm{CO}$ on insulin secretion [27]. For critically ill patients on the ICU however, markers of oxidative stress will be non-specific for high blood glucose, as they increase with any form of oxidative stress such as sepsis, high inspired-oxygen fraction and acute respiratory distress syndrome [40].

\section{Study design}

The observed correlation between blood glucose levels and exhaled VOCs may be due to the inclusion of T2DM patients and/or a cross-sectional study design. First, T2DM influences the responsiveness of the body to changes in blood glucose levels [41]. This is typically characterized by insulin resistance but may also influence the formation of ketone bodies and the induction of liver enzymes. Second, breath acetone levels tend to differ between T1DM, T2DM, and healthy subjects $[18,21,35]$. Therefore, a decrease in blood glucose levels may not induce the same rise in breath acetone levels with different baseline values and in the context of different comorbidities. Finally, in line with the previous point, correction for baseline differences between subjects cannot be accomplished with a cross-sectional study design. This is further acknowledged by the fact that the predictive algorithm requires calibration for every subject in several studies $[20,22]$. Since the relation between exhaled breath metabolites and blood glucose levels shows high interperson variation, a cross-sectional design may not be ideal for predicting glucose levels using breath metabolites. The possibility of using a single breath maneuver to estimate blood glucose levels thus seems implausible. Future studies may therefore focus on longitudinal measurements in the same subject.

Five included studies used a clamp study design and 2 studies used an oral glucose tolerance test (OGTT). Clamp studies and OGTT result in a more or less predictable course of blood glucose levels. Although a clamp design is ideal for research purposes and enables 
comparability between studies, clinical practice is often very different and less predictable. The transition of the results of these studies to the clinical setting will be a major challenge for the field of blood glucose estimation by exhaled breath analysis.

\section{Strengths and limitations}

We used a standardized systematic review approach, combining all evidence available. All VOCs that are linked to changes in glucose levels are discussed and their most likely biochemical pathways are described. In addition, we carefully assessed the quality of the included studies.

This systematic review also has an important limitation. The included studies were highly heterogeneous with respect to patient selection, exhaled breath sampling and analysis and blood glucose measurement, limiting the comparability of the studies. Therefore, we decided to describe the results separately. Most of the included studies had a relatively high risk of bias and we found that included studies did not validate their results. Possibly, this is inevitable in the early stages of biomedical research but it hinders strong conclusions. Furthermore, models can possibly be overfit, yielding overoptimistic results. Our search only identified one negative study. Negative studies are often not published leading to publication bias.

None of the studies investigated ICU-patients, while glucose fluctuations are large and frequent in this population [42]. Therefore, we cannot draw firm conclusions on the use of these methods in ICU-patients. We did try to identify potential pitfalls for the implementation of these methods in ICU patients by reviewing the biochemical pathways for the formation of VOCs.

Finally, the use of exhaled breath to monitor glucose trends was not discussed in any of the articles. Monitoring glucose trends (in ICU patients) however, has several potential advantages over using single values. First, trend has a better predictive value compared to single glucose levels; recent trend can be used to predict future levels. In ICU patients, this can lead to improved insulin titration. Second, because outliers can be filtered out, trend is less susceptible to random noise. Third, possible bias (constantly predicting values too high/low) will be constant throughout the trend, having a smaller effect. Potential disadvantages of using glucose trend are possible lag in the signal, and the potential of amplification of errors.

\section{Conclusion}

In conclusion, a significant association between VOCs in exhaled breath and blood glucose levels was found in the majority of studies included in this systematic review. Acetone, carbon monoxide, ethanol, ethyl benzene, $\mathrm{M} / \mathrm{P}$-xylene, methanol, O-xylene, and propane were correlated with blood glucose levels. Several potential effect modifiers were identified for ICU-patients. The included studies were performed under highly controlled circumstances, which limit generalizability. Our results warrant clinical validation of exhaled breath analysis for the monitoring of blood glucose levels in critically ill ICUpatients.

\section{Additional file}

Additional file 1: QUADAS-2 - Adapted for systematic review on Glucose Prediction by Analysis of Exhaled Metabolites.

\section{Abbreviations}

CO: Carbon monoxide; GC-MS: Gas chromatography and mass spectrometry; ICU: Intensive care unit; IMS: Ion-mobility spectroscopy; OGTT: Oral glucose tolerance test; PTR-(TOF)-MS: Proton transfer reaction (time of flight) mass spectrometry; SIFT-MS: Selected ion flow tube mass spectrometry; T1DM: Type 1 diabetes mellitus; T2DM: Type 2 diabetes mellitus; VOC: Volatile organic compound.

\section{Competing interests}

The authors declare that they have no competing interests.

\section{Authors' contributions}

$\mathrm{JHL}$ designed the review, extracted the data, summarized the findings, and composed the manuscript. RTMvH participated in the study design and contributed to the manuscript. PJS participated in the study design and contributed to the manuscript. AAH participated in the study design and contributed to the manuscript. MJS participated in the study design, contributed to the manuscript and coordinated the team efforts. LDB participated in the study design, extracted the data, summarized the findings and contributed to the manuscript. All authors read and approved the final manuscript.

\section{Acknowledgements}

LDJB is supported by a research grant (PhD Scholarship) of the Academic Medical Center (https://www.amc.nl/web/Onderwijs/PhD/AMC-Scholarships/ AMC-PhD-Scholarships-2014.htm -winners.htm), by an unrestricted research grant from Philips Research and by the ESICM Young Investigator Award (http://www.esicm.org/research/awards). None of these funding bodies had any role in design, in the collection, analysis, and interpretation of data; in the writing of the manuscript; and in the decision to submit the manuscript for publication.

\section{Financial support}

All funding came from departmental sources.

\section{Author details}

${ }^{1}$ Department of Intensive Care, Academic Medical Center, Meibergdreef 9 1105 AZ Amsterdam, The Netherlands. 'Department of Medical Informatics, Academic Medical Center, Meibergdreef 9, 1105 AZ Amsterdam, The Netherlands. ${ }^{3}$ Department of Respiratory Medicine, Academic Medical Center, Meibergdreef 9, 1105 AZ Amsterdam, The Netherlands.

Received: 5 March 2014 Accepted: 3 June 2014

Published: 17 June 2014

\section{References}

1. Schultz MJ, Spronk PE, van Braam Houckgeest F: Glucontrol, no control, or out of control? Intensive Care Med 2010, 36:173-174. author reply 175-6.

2. Schultz MJ, Harmsen RE, Spronk PE: Clinical review: strict or loose glycemic control in critically ill patients-implementing best available evidence from randomized controlled trials. Crit Care 2010, 14:223.

3. Finfer S, Wernerman J, Preiser J-C, Cass T, Desaive T, Hovorka R, Joseph J,, Kosiborod M, Krinsley J, Mackenzie I, Mesotten D, Schultz MJ, Scott MG, Slingerland R, Van den Berghe G, Van Herpe T: Clinical review: consensus recommendations on measurement of blood glucose and reporting glycemic control in critically ill adults. Crit Care 2013, 17:229. 
4. Aragon D: Evaluation of nursing work effort and perceptions about blood glucose testing in tight glycemic control. Am J Crit Care 2006, 15:370-377.

5. Karon BS, Boyd JC, Klee GG: Glucose meter performance criteria for tight glycemic control estimated by simulation modeling. Clin Chem 2010, 56:1091-1097.

6. Shaham O, Wei R, Wang TJ, Ricciardi C, Lewis GD, Vasan RS, Carr SA, Thadhani R, Gerszten RE, Mootha VK: Metabolic profiling of the human response to a glucose challenge reveals distinct axes of insulin sensitivity. Mol Syst Biol 2008, 4:214

7. Duarte NC, Becker SA, Jamshidi N, Thiele I, Mo ML, Vo TD, Srivas R, Palsson B $\varnothing$ : Global reconstruction of the human metabolic network based on genomic and bibliomic data. Proc Natl Acad Sci U S A 2007, 104:1777-1782

8. Wopereis S, Rubingh CM, van Erk MJ, Verheij ER, van Vliet T, Cnubben NHP Smilde AK, van der Greef J, van Ommen B, Hendriks HFJ: Metabolic profiling of the response to an oral glucose tolerance test detects subtle metabolic changes. PLoS One 2009, 4:e4525

9. Bijland LR, Bomers MK, Smulders YM: Smelling the diagnosis: a review on the use of scent in diagnosing disease. Neth J Med 2013, 71:300-307.

10. Roberts $K$, Jaffe A, Verge C: Noninvasive monitoring of glucose levels: is exhaled breath the answer? J Diabetes Sci Technol 2012, 6:659-664.

11. Turner C: Potential of breath and skin analysis for monitoring blood glucose concentration in diabetes. Expert Rev Mol Diagn 2011, 11:497-503.

12. Minh TDC, Blake DR, Galassetti PR: The clinical potential of exhaled breath analysis for diabetes mellitus. Diabetes Res Clin Pract 2012, 97:195-205.

13. Khan KS, Kunz R, Kleijnen J, Antes G: Five steps to conducting a systematic review. J R Soc Med 2003, 96:118-121.

14. Liberati A, Altman DG, Tetzlaff J, Mulrow C, Gøtzsche PC, loannidis JPA, Clarke M, Devereaux PJ, Kleijnen J, Moher D: The PRISMA statement for reporting systematic reviews and meta-analyses of studies that evaluate healthcare interventions: explanation and elaboration. BMJ 2009, 339:b2700.

15. Whiting PF, Rutjes AWS, Westwood ME, Mallett S, Deeks JJ, Reitsma JB, Leeflang MMG, Sterne JAC, Bossuyt PMM, Group Q-2: QUADAS-2: a revised tool for the quality assessment of diagnostic accuracy studies. Ann Intern Med 2011, 155:529-536.

16. Kanji S, Buffie J, Hutton B, Bunting PS, Singh A, McDonald K, Fergusson D, McIntyre LA, Hébert PC: Reliability of point-of-care testing for glucose measurement in critically ill adults. Crit Care Med 2005, 33:2778-2785.

17. Righettoni M, Schmid A, Amann A, Pratsinis SE: Correlations between blood glucose and breath components from portable gas sensors and PTR-TOF-MS. J Breath Res 2013, 7:037110.

18. Storer M, Dummer J, Lunt H, Scotter J, McCartin F, Cook J, Swanney M, Kendall D, Logan F, Epton M: Measurement of breath acetone concentrations by selected ion flow tube mass spectrometry in type 2 diabetes. J Breath Res 2011, 5:46011.

19. Fritsch $T$, van Herpen $M$, von Basum G, Hering P, Murtz M: Is exhaled carbon monoxide level associated with blood glucose level? A comparison of two breath analyzing methods. J Biomed Opt 2008, 13:34012

20. Lee J, Ngo J, Blake D, Meinardi S, Pontello AM, Newcomb R, Galassetti PR: Improved predictive models for plasma glucose estimation from multi-linear regression analysis of exhaled volatile organic compounds. J Appl Physiol 2009, 107:155-160.

21. Turner C, Walton C, Hoashi S, Evans M: Breath acetone concentration decreases with blood glucose concentration in type I diabetes mellitus patients during hypoglycaemic clamps. J Breath Res 2009, 3:46004.

22. Minh TDC, Oliver SR, Ngo J, Flores R, Midyett J, Meinardi S, Carlson MK, Rowland FS, Blake DR, Galassetti PR: Noninvasive measurement of plasma glucose from exhaled breath in healthy and type 1 diabetic subjects. Am J Physiol Endocrinol Metab 2011, 300:E1166-E1175.

23. Boots AW, van Berkel JJ, Dallinga JW, Smolinska A, Wouters EF, Van Schooten FJ: The versatile use of exhaled volatile organic compounds in human health and disease. J Breath Res 2012, 6:27108.

24. White IR, Willis KA, Whyte C, Cordell R, Blake RS, Wardlaw AJ, Rao S, Grigg J, Ellis AM, Monks PS: Real-time multi-marker measurement of organic compounds in human breath: towards fingerprinting breath. J Breath Res 2013, 7:17112.

25. Jordan A, Haidacher S, Hanel G, Hartungen E, Märk L, Seehauser H, Schottkowsky $R$, Sulzer $P$, Märk TD: A high resolution and high sensitivity proton-transfer-reaction time-of-flight mass spectrometer (PTR-TOF-MS). Int J Mass Spectrom 2009, 286:122-128.
26. Spanĕl P, Smith D: Selected ion flow tube mass spectrometry for on-line trace gas analysis in biology and medicine. Eur J Mass Spectrom (Chichester, Eng) 2007, 13:77-82

27. Paredi P, Biernacki W, Invernizzi G, Kharitonov SA, Barnes PJ: Exhaled carbon monoxide levels elevated in diabetes and correlated with glucose concentration in BloodA new test for monitoring the disease? CHEST J 1999, 116:1007-1011

28. Dolch ME, Frey L, Hornuss C, Schmoelz M, Praun S, Villinger J, Schelling G: Molecular breath-gas analysis by online mass spectrometry in mechanically ventilated patients: a new software-based method of $\mathrm{CO}(2)$-controlled alveolar gas monitoring. J Breath Res 2008, 2:37010.

29. Bos LDJ, van Walree IC, Kolk AHJ, Janssen H-GH-G, Sterk PJ, Schultz MJ: Alterations of exhaled breath metabolite-mixtures in two rat models of lipopolysaccharide-induced lung injury. J App/ Physiol 2013, 115: jap.00685.2013.

30. Konvalina G, Haick H: Sensors for breath testing: from nanomaterials to comprehensive disease detection. Acc Chem Res 2013, 47:66-76.

31. Dalton P, Gelperin A, Preti G: Volatile metabolic monitoring of glycemic status in diabetes using electronic olfaction. Diabetes Technol Ther 2004, 6:534-544.

32. Galassetti PR, Novak B, Nemet D, Rose-Gottron C, Cooper DM, Meinardi S, Newcomb R, Zaldivar F, Blake DR: Breath ethanol and acetone as indicators of serum glucose levels: an initial report. Diabetes Technol Ther 2005, 7:115-123.

33. Pavlou AK, Turner AP: Sniffing out the truth: clinical diagnosis using the electronic nose. Clin Chem Lab Med 2000, 38:99-112.

34. Wang C, Mbi A, Shepherd M: A Study on breath acetone in diabetic patients using a cavity ringdown breath analyzer: exploring correlations of breath acetone with blood glucose and glycohemoglobin A1C Sensors Journal, IEEE 2010, 10:54-63.

35. Deng C, Zhang J, Yu X, Zhang W, Zhang X: Determination of acetone in human breath by gas chromatography-mass spectrometry and solidphase microextraction with on-fiber derivatization. J Chromatogr B Analyt Technol Biomed Life Sci 2004, 810:269-275.

36. Spanĕl $P$ : Acetone, ammonia and hydrogen cyanide in exhaled breath of several volunteers aged 4-83 years. J Breath Res 2007, 1:11001.

37. Hillman KM, Riordan T, O'farrell SM, Tabaqchali S: Colonization of the gastric contents in critically patients. Crit Care Med 1982, 10:444.

38. Bos LDJ, Wang Y, Weda H, Nijsen TME, Janssen APGE, Knobel HH, Vink TJ, Schultz MJ, Sterk PJ: A simple breath sampling method in intubated and mechanically ventilated critically ill patients. Respir Physiol Neurobiol 2013, 191C:67-74.

39. Novak BJ, Blake DR, Meinardi S, Rowland FS, Pontello A, Cooper DM, Galassetti PR: Exhaled methyl nitrate as a noninvasive marker of hyperglycemia in type 1 diabetes. Proc Natl Acad Sci U S A 2007, 104:15613-15618.

40. Crader MK, Repine DJJ: Breath Biomarkers and the Acute Respiratory Distress Syndrome. J Pulm Respir Med 2012, 2:1-9.

41. Grapov D, Adams SH, Pedersen TL, Garvey WT, Newman JW: Type 2 diabetes associated changes in the plasma non-esterified fatty acids: oxylipins and endocannabinoids. PLOS One 2012, 7:e48852.

42. McCowen KC, Malhotra A, Bistrian BR: Stress-induced hyperglycemia. Crit Care Clin 2001, 17:107-124.

doi:10.1186/1471-2253-14-46

Cite this article as: Leopold et al:: Glucose prediction by analysis of exhaled metabolites - a systematic review. BMC Anesthesiology 2014 14:46 